\title{
Mitologi Host Cerdas 5 Menit Metro TV
}

\author{
Patricia Robin \\ Universitas Bunda Mulia, Tangerang, Banten, Indonesia
}

\begin{abstract}
ABSTRAK
Televisi sebagai salah satu media masa, dihandalkan perusahaan (penjual barang ataupun penawar jasa) untuk mengomunikasikan produknya dengan cara yang begitu "lembut" dan "elegan". Hal ini tidak lain lantaran dalam menjalankan fungsi informasi, edukasi, dan hiburannya, televisi sarat kepentingan dan ideologi yang berlomba mempengaruhi audiens. Talk show berkekuatan "menyihir" pemirsa lantaran bersanding dengan setting (visual) santai dan paparan percakapan (audio) yang membuat perbincangan mudah dicerna. Makna, mitologi dan ideologi yang terselubung dalam setiap tanda verbal dan nonverbal host Cerdas 5 Menit Metro TV layak dikaji secara mendalam. Penelitian ini menggunakan teori terkait kajian kritis semiotika, talk show, serta kajian elemen verbal dan nonverbal. Adapun paradigma kritis berjalan beriringan dengan teori semiotika Roland Barthes berfungsi sebagai pisau analisis yang mengkaji pesan linguistik, pesan ikonik terkodekan dan pesan ikonik tidak terkodekan. Hasil penelitian yang didapatkan adalah pergeseran makna atas tanda verbal dan nonverbal Chandra Dewi selaku host, baik dari segi ekspresi, gerakan kepala dan tangan, hingga pelafalan dan atribut yang digunakan berikut elemen pendukung keberadaannya sebagai host Cerdas 5 Menit. Hal ini dirangkum dalam 4 mitologi kunci, antara lain transformasi makna, gaya hidup, keberpihakan, serta kepentingan materialistis. Keempat mitologi ini mengantarkan pada ideologi kapitalisme yang dimiliki oleh host Cerdas 5 Menit Metro TV.
\end{abstract}

\section{ABSTRACT}

Talk shows have the power to "bewitch" the audience because they are coupled with a relaxed (visual) setting and conversation exposure (audio) that makes the conversation easy to digest. The meaning, mythology, and ideology that are shrouded in every verbal and nonverbal sign of Host at the "Cerdas 5 Menit Metro TV" deserve to be studied in depth. This study uses theories related to semiotic critical studies, talk shows, and the study of verbal and nonverbal elements. The critical paradigm goes hand in hand with the theory of semiotics Roland Barthes functions as a knife of analysis that examines linguistic messages, coded iconic messages and uncoded iconic messages. The results obtained are a shift in the meaning of verbal and nonverbal signs Chandra Dewi as the host, both in terms of expression, head and hand movements, to pronunciation and attributes used along with supporting elements of its existence as a Host at the "Cerdas 5 Menit Metro TV". This is summarized in 4 key mythologies, including the transformation of meaning, lifestyle, partisanship, and materialistic interests. These four mythologies usher in the ideology of capitalism that is owned by Host at the "Cerdas 5 Menit Metro TV".

\author{
KATA KUNCI \\ Talk show; \\ Semiotika Roland \\ Barthes; \\ Transformasi \\ Makna; Kapitalisme
}

\section{KEYWORDS}

Talk show; Roland Barthes Semiotics; Transformation of Meaning; Capitalism 


\section{PENDAHULUAN}

Perwujudan masyarakat jaman now terlihat dari eksistensi mereka yang erat dengan terpaan informasi dan teknologi di ranah dunia maya. Setiap orang ingin dikenal dan menjadi yang terdepan dibanding lainnya, walaupun gaya tersebut tidak sesuai dengan keadaan pribadi yang sesungguhnya. Artikel "Yang Penting Gaya" dalam kompas.com menggambarkan keadaan masyarakat dimana secara finansial sulit terealisasi. Kepemilikan kartu kredit, tawaran promo ataupun cicilan akhirnya menjadi sajian menggiurkan yang membuat masyarakat menjadi lebih konsumtif. Pengaturan finansial akan bertambah sulit ketika hutang yang dimiliki semakin besar secara kuantitas. Hal ini disebabkan kewajiban membayar pokok hutang ditambah dengan bunga.

Tema ini dilirik oleh Metro TV sebagai "Cerdas 5 Menit" yang ditayangkan secara regular. Program ini mempunyai format talk show, yang terdiri satu host berbincang dengan satu narasumber ahli. Tema dalam acara tersebut menyangkut keseharian masyarakat urban dan permasalahan keuangan masyarakat pada umumnya. Tayangan ini menjadi unik karena Manulife Indonesia sebagai sponsor tunggal dan juga penyelenggara tidak memaparkan produk jasa yang dijual dalam pembahasan di awal, melainkan di akhir dari acara tersebut.

Ranah media massa menjadi ajang pertarungan antar pihak yang berkepentingan yang menawarkan berbagai keperluan yang dibutuhkan oleh individu masa kini. Isi yang ditawarkan mempengaruhi cara berpikir, merasakan dan bertingkah laku manusia itu sendiri. Ironisnya, hal ini terkadang tidak diiringi kemampuan manusia dalam memilah informasi mana yang layak serta tidak layak untuk diterima, disaring, lalu diinterpretasikan.

Isi media massa hanyalah hasil konstruksi realitas dengan bahasa sebagai perangkat dasarnya. Bahasa tidak hanya sebagai alat merepresentasikan realitas, juga menentukan relief yang diciptakan atas realitas tersebut. Tidak ada satupun media massa yang mampu memberikan informasi yang dikemas ke dalam suatu berita secara netral. Semuanya hasil konstruksi realitas sebagai upaya menampilkan wacana yang "bermakna". Hal ini juga terjadi pada media televisi. Dalam penyajian tayangan dan beritanya, televisi tidak lepas dari tangan kepentingan yang ingin memuaskan hasrat pengerukan uang oleh pemilik modal ataupun pemerintah (Sobur, 2009, p. 88).

Eksplorasi makna tanda yang terdapat pada host Cerdas 5 Menit dilakukan menggunakan pisau analisis semiotik sebagai ilmu interpretasi "tanda" yang tidak pernah membawa makna tunggal terutama ketika ditampilkan di media massa. Teks media selalu memiliki ideologi dominan yang membawa kepentingan, juga kesalahan tertentu yang luas dan kompleks. Dengan demikian, semiotika mempelajari hakikat tentang keberadaan suatu tanda yang oleh Umberto Eco disebut sebagai kebohongan, yaitu di dalam tanda ada sesuatu yang tersembunyi di belakangnya, bukan tanda itu 
sendiri. Pemaknaan setiap individu bersifat subjektif, yang artinya setiap individu memiliki interpretasi dan pengalaman yang berbeda dalam melihat fenomena. Semiotika Roland Barthes yang menekankan pada konotasi dan mitos serta pembongkaran ideologi yang ada dalam sebuah teks adalah pisau yang pas (Sobur, 2009 , p. 86). Dalam penelitian dipaparkan mengenai keberadaan host yang merupakan sentral dan panggung terdepan media massa dalam memaparkan isinya.

Dalam penelitian yang dilakukan oleh Rita Martasari pada 2007 dengan judul "Dekonstruksi Host Dalam Talk Show Di Televisi (Analisis Semiotik Talk Show Empat Mata di Trans 7)", dipaparkan bahwa perkembangan program acara televisi di Indonesia cukup beraneka ragam dan mengikuti perkembangan zaman. Keberadaan host bukan sekedar pemanis semata, melainkan menjadi kunci karena terkadang sosoknya menjadi ikon dan merepresentasikan sempurna keberadaan acara keseluruhan.

Host dalam talk show di televisi mempunyai peran yang penting dalam membawakan acara talk show tersebut pada kelancaran hingga kesuksesan acara hingga acara tersebut berakhir. Pada dasarnya konsep host telah mempunyai konstruksi sendiri yang telah lama dipakai dalam dunia host televisi. Namun seiring dengan kreativitas para kreator program televisi yang semakin berkembang dan memikirkan akan originalitas sebuah acara khususnya acara talk show, maka konstruksi host itu sendiri telah diubah atau dihancurkan dengan konsep host yang telah mereka buat sendiri (Martasari, 2007).

Peneliti mencurigai bagaimana sebuah konten asuransi beralih fungsi menjadi wujud tayangan informatif yang diterima mentah oleh masyarakat sebagai sajian talk show biasa. Peneliti melihat selain dari sisi bahasa, juga dari sisi nonverbal yang digunakan oleh host, baik itu ekspresi wajah, pakaian yang digunakan, gerakan tangan, penekanan kata dan lainnya. Penelitian ini penting dilakukan untuk memahami makna denotasi, konotasi serta mitologi hingga ideologi dalam sebuah iklan berbentuk talk show.

Dalam setiap elemennya, terdapat konstruksi yang tertuang dalam pemilihan host, penyusunan kata (tanda verbal), gestur dan penekanan kata (nonverbal), hingga pemilihan shot yang menjadikan iklan tersebut bermakna. Pembahasan ini penting dalam memperkaya pembahasan terkait Ilmu Komunikasi (khususnya media massa), juga bagi masyarakat dan pemilik iklan. Hal ini yang akan membongkar bagaimana kepentingan di dalam iklan di dalamnya "bermain" ketika tayang di hadapan audience.

Adapun penelitian ini bertujuan untuk (1) Mengungkap makna tanda host Cerdas 5 Menit Episode Sampai Kapan Gaya Dari Utang (Chandra Dewi); (2) Mengungkap pemaknaan yang muncul atas setiap tanda verbal dan nonverbal host Cerdas 5 Menit Episode Sampai Kapan Gaya Dari Utang (Chandra Dewi) yang tayang pada 19 Juli 2018; (3) Mengidentifikasi mitologi dan ideologi dari tanda verbal dan nonverbal host Cerdas 
5 Menit Episode Sampai Kapan Gaya Dari Utang (Chandra Dewi) yang tayang pada 19 Juli 2018.

Tradisi semiotika sebagai salah satu dari tujuh tradisi ilmu komunikasi dipilih peneliti sebagai pijakan utama desain penelitian berupa Semiotika Roland Barthes. Peneliti menggunakan dua teori pendukung antara lain terkait verbal dan nonverbal serta terkait gaya hidup atau konsumerisme. Hal ini ditempuh peneliti untuk mengungkap makna serta mitologi dan ideologi dari verbal dan nonverbal host Cerdas 5 Menit Episode Sampai Kapan Gaya Dari Utang. Penelitian ini akan dirunut dengan menggunakan semiotika Roland Barthes. Model ini mengangkat denotasi dan konotasi untuk menganalisis tanda berbentuk karya fisik yang dapat diindrai oleh manusia seperti karya sastra dan gejala kebudayaan, mode pakaian, lirik lagu, film dan lainnya (Barthes, 2010).

Bagi Barthes komponen tanda, penanda - petanda terdapat juga pada tanda yang bukan berbentuk bahasa, yaitu pada mitos yang merupakan keseluruhan sistem citra dan kepercayaan yang dibentuk masyarakat untuk mempertahankan dan menonjolkan identitasnya. Teori mitos atau mitologi dikembangkan oleh Barthes untuk melakukan kritik atas ideologi budaya massa atau budaya media. Mitos adalah suatu wahana dimana ideologi berwujud. Mitos dapat berangkai menjadi mitologi yang memainkan peranan penting dalam kesatuan-kesatuan budaya. Van Zoest (1991) dalam (Wibowo, 2011, p. 17) menegaskan, siapapun bisa menemukan ideologi dalam teks dengan jalan meneliti konotasi-konotasi yang terdapat di dalamnya.

Selanjutnya, penggunaan makna konotasi di masyarakat secara terus menerus akan membentuk suatu ideologi atau makna tingkat ketiga. Secara etimologis ideologi berasal dari bahasa Greek, terdiri atas kata idea (Idein) yang berarti melihat dan logos (logia) yang berarti kata-kata atau pengetahuan dan teori. Tidak ada satupun aktivitas penggunaan tanda yang bukan ideologi karena ideologi sangat dominan dalam eksistensinya. Ideologi merupakan kesadaran semu yang menjadi sistem kepercayaan yang dibuat-buat kemudian menjadi pegangan bagi individu untuk menggunakannya sebagai suatu "bahasa" sehingga membentuk orientasi sosial dan akhirnya berusaha berperilaku selaras dengan ideologi (Wibowo, 2011, p. 18).

Semiotika merupakan studi yang digunakan untuk meneliti secara mendalam mengenai apa yang terdapat di bahasa. Bahasa adalah seperangkat kata yang disusun secara berstruktur sehingga menjadi suatu kalimat yang mengandung makna. Dalam penggunaannya, bahasa merupakan alat komunikasi yang membedakan manusia dengan makhluk hidup lainnya. Manusia tidak dapat menyampaikan gagasan, menolak atau menerima yang ditawarkan kepadanya dan bersosialisasi dengan masyarakat tanpa adanya bahasa (Suprapto, 2006, p. 4-5). 
Makna merupakan hakekat komunikasi yang ada dalam setiap komunikasi yang dilakukan baik itu pengirim dan penerima pesan. Pemaknaan berada dalam koridor mencari kebenaran, melalui langkah-langkah kreatif dalam memberi makna. Dalam beberapa budaya, kata-kata dan makna kata-kata tersebut tidak mempunyai hubungan langsung (DeVito, 2012).

Perilaku nonverbal tampak "alamiah" karena diperoleh secara osmotik (tanpa dipikirkan) dalam konteks kultural. Pada kenyataannya, perilaku ini sebagian besar berasal dari kesepakatan menurut sejarah bukan dari adanya kewajaran atau ketidakwajaran. Atas hal ini, setiap pesan yang dibuat dengan tanda nonverbal selalu melibatkan konotasi atau jarang ditafsirkan sebagai murni sinyal fisik. Tanda bisa berasal dari diri sendiri, pakaian, kosmetik dan hiasan tubuh lainnya yang merupakan wujud representasi diri. Secara intrinsik dapat menunjukkan makna seksual, romantis, dan pacaran seperti contoh adalah pemberian kalung dengan kombinasi manik merah muda dan putih. Beberapa suku menyatakan hal tersebut sebagai "kau miskin, tetapi aku tetap mencintaimu". Ini menunjukkan betapa luas tanda yang ada di sekeliling kita dengan beragam makna denotasi dan konotasi tercakup di dalamnya (Danesi, 2010).

Wajah. Ekspresi wajah tidak dipelajari melainkan sudah ditentukan secara biologis. Ahli Psikologi Paul Ekman beserta rekan-rekannya menyatakan bahwa sedikit sekali variasi dalam berbagai budaya dari segi sifat komponen dan kombinasinya. Elemen-elemen yang menentukan tersebut adalah tanda universal bagi emosi-emosi spesifik dengan pembagian ke dalam beberapa karakteristik yaitu posisi alis, bentuk mata, bentuk mulut, ukuran lubang hidung dalam berbagai kombinasi akan menentukan bentuk, $\mathrm{X}$, dan makna, Y, dari ekspresi yang bersangkutan (Danesi, 2010, p. 69).

Kosmetik. Kecenderungan orang untuk mengevaluasi orang lain berdasarkan penampilan dari wajah sebagai tanda diri. Kehadiran sosok seorang host di TV bukan hanya dilihat dari kemampuannya membawakan acara, melainkan faktor wajah turut menjadi "alat perang" yang jitu dalam menunjang penampilan supaya tampak lebih menarik, cantik dan sedap dipandang (Danesi, 2010, p.70).

Mata. Mata merupakan indra yang paling ekspresif yang dapat digunakan untuk mengkualifikasi pandangan mata, seperti bahagia, dendam, kejam, licik, melankolis, nakal, polos, ramah, redup, sendu, dan lainnya (Danesi, 2010, p. 75).

Gigi. Menurut Erving Goffman, gigi memainkan peran dalam penampilan dan ekspresi wajah. Hal ini yang membuat banyak perusahaan perawatan gigi membuat produkproduk seperti pasta gigi, pemutih gigi, penyegar nafas, pencegah gigi berlubang, penghilang plak dan benang pembersih gigi agar tampilan gigi seseorang lebih menarik jika orang tersebut tersenyum (Berger dan Luckmann, 1990, p. 91). 
Rambut. Industri yang berkaitan dengan rambut juga berkembang pesat, baik dalam bentuk salon, shampoo, pewarna rambut ataupun produk kecantikan untuk membuat rambut tampak indah dan menarik. Rambut sebagai mahkota yang sangat menonjol dari manusia, diberikan perhatian khusus terutama dalam dunia media massa (televisi) (Berger dan Luckmann, 1990, p. 84).

Penampilan dan Bahasa Tubuh. Beberapa studi juga menunjukkan bahwa bentuk tubuh seseorang akan mempengaruhi perilakunya. Kretschmer (1970) membagi orang yang mempunyai kesamaan morfologis ke dalam tiga kelompok yaitu kelompok asthenic atau orang yang ditandai dengan bentuk tubuh yang sempit, kurus, dan tampak tulangtulangnya; orang yang berada pada kelompok athletic atau orang yang mempunyai bentuk tubuh yang berotot; dan kelompok pyknic atau orang yang memiliki tubuh gendut (Sihabudin, 2011, p.100).

Fashion. Georg Simmel, sosiolog besar Jerman, menjelaskan bahwa busana memiliki valensi ganda. Di satu sisi, hal itu memisahkan dan membedakan kita dari orang lain, tetapi di sisi lain, hal tersebut membuat kita terintegrasi dalam masyarakat serta kelompok dan subkultur yang serupa. Kaum elite umumnya menggunakan fashion merek terkenal dunia, sedangkan kaum marjinal meniru dengan gaya yang berbeda dengan kaum elite dengan mencari sesuatu yang baru. Hal ini yang membuat fashion akan terus berkembang lantaran selalu ada unsur perlawanan (Berger dan Luckmann, 1990, p. 77-78).

Pakaian dan fashion menawarkan kepada manusia kesempatan untuk membuat berbagi macam pesan dan makna. Dalam studi semiotika terhadap pakaian, tidak sekedar membincang studi kelangsungan hidup secara fisik. Sebaliknya, studi ini mempelajari kecenderungan untuk mengubah apapun yang kita letakkan pada tubuh sebagai tanda (Danesi, 2010, p. 274).

Warna dan Makna. Penggunaan istilah warna dalam konotatif tersebar lebih luas ketimbang yang kita bayangkan. Beberapa contoh istilah dalam bahasa Inggris seperti red, blue dan green, akan mengantar kita pada ragam konsep konotasi. Kata-kata seperti red carpet, red tape, the blues, true blue, green horn, green envy menunjukkan bahwa ia bukanlah sekedar kata-kata belaka melainkan penuh makna mulai dari perlakuan istimewa, birokratis, setia, orang yang tidak berpengalaman, rasa iri, sampai dengan jenis musik. Ungkapan-ungkapan membuat persepsi warna lebih dari sekedar fenomenon yang melibatkan persepsi visual semata. Dalam setiap masyarakat, warna memainkan fungsi yang sangat penting dalam wilayah simbolisme (Danesi, 2010, p. 103-104).

Elemen Gambar pada tayangan Televisi. Dibangun atas susunan tanda yang penuh ideologi, kiranya televisi juga memiliki tujuan terselubung dalam penyajian gambarnya. Setelah membahas tampilan nonverbal yang didapat dari sosok person (host), bagian 
lain yang tidak dapat dipisahkan adalah elemen dalam gambar televisi. Hal ini terkait teknik penggunaan kamera, lensa yang digunakan, ataupun penentuan sudut pandang, fokus dan warna (Selby dan Cowdery, 1995, p. 57-58).

\section{METODOLOGI PENELITIAN}

Penelitian kualitatif ini menggunakan teks dan video yang menjadi bahan untuk analisa dan interpretasi. Pemaknaan dianggap oleh peneliti sebagai suatu wujud yang tidak terbatas dan selalu siap dibongkar lantaran mengandung beragam kepentingan di belakangnya. Tanda Verbal dan Non-Verbal yang kian banyak digunakan dalam kehidupan sehari-hari dan juga digunakan di media massa oleh setiap pemeran di dalamnya seperti berita, ataupun tayangan non berita yang begitu dekat dengan keseharian seperti talk show.

Dalam penelitian lanjutan, tanda verbal dan non-verbal masih menjadi kajian utama peneliti. Hal ini semakin spesifik dengan isu sosial maupun politik yang akan semakin marak. Penelitian ini pada akhirnya mampu mengidentifikasi pemaknaan dari berbagai aspek yang akhirnya memberikan deskripsi yang menyeluruh tentang ideologi televisi pada umumnya, atau tayangan berita pada khususnya.

Penelitian ini dilakukan dari bulan Oktober 2018 sampai dengan Juni 2019. Penelitian ini terbagi dalam beberapa point antara lain pemaparan pesan linguistik, pesan ikonik yang terkodekan, serta pesan ikonik yang tak terkodekan dari host Cerdas 5 Menit Episode Sampai Kapan Gaya Dari Utang (Chandra Dewi).

Pada bulan Juli 2018 iklan ini diunggah pada media sosial YouTube dengan durasi lima menit. Peneliti memfokuskan pada seluruh tampilan visual host tayangan tersebut yang sarat akan makna. Peneliti memilih topik gaya hidup dari talk show tersebut untuk dijadikan sebagai unit analisis penelitian, karena peneliti melihat paparan ini sering dilakukan dalam program tersebut yang nantinya menggiring dalam sebuah pesan persuasif yaitu beriklan tentang Manulife Indonesia (perusahaan asuransi).

Teknik analisa data dilakukan dengan model analisis semiotik Roland Barthes, dikenal signifikansi dua tahap yang berusaha memaparkan makna denotasi dan konotasi dari penerima tanda yang akan membangun mitos tersendiri. Denotasi merupakan tingkat pertandaan yang menjelaskan hubungan penanda dan petanda pada realitas, menghasilkan makna eksplisit, langsung dan pasti (Rusmana, 2014). Denotasi memiliki referen realitas eksternal yang harus ditemukan terlebih dahulu untuk kemudian dipersepsi kembali. Berbalik dengan konotasi yang adalah tingkat pertandaan yang menjelaskan hubungan penanda dan petanda yang di dalamnya beroperasi makna yang tidak eksplisit, tidak langsung dan tidak pasti (Piliang, 2010). 
Dari situlah penelitian ini berlanjut dengan pengkajian yang bertujuan membongkar ideologi yang ada sehingga membangun paparan baru yang siap untuk dimaknai lagi, baik secara denotatif atau konotatif. Hasil penelitian atau pengumpulan data berbentuk uraian mendalam bukan angka seperti penelitian kuantitatif.

Dengan membuka wilayah pemaknaan konotatif, penerima tanda memahami penggunaan gaya bahasa terselubung yang tidak dapat dianalisis melalui level denotatif. Pembaca dapat memaknai bahasa metafor atau majazi yang hanya dapat dipahami pada tataran konotatif. Konotasi tidak pernah menghabiskan apa yang akan dibahas, selalu saja tertinggal 'sesuatu yang tertunjukkan'. Penanda konotatif memberikan makna tambahan, namun juga mengandung tanda denotatif yang melandasi keberadaannya (Sobur, 2009, p. 100).

Penelitian ini berfokus pada makna tanda verbal dan nonverbal dari host Cerdas 5 Menit Episode Sampai Kapan Gaya Dari Utang (Chandra Dewi). Peneliti merupakan partisipan aktif, memulai langkah penelitian didasarkan pada suatu kecurigaan akan adanya makna dan mitologi serta ideologi terselubung yang tersaji dalam tayangan tersebut. Sesuai dengan ranah paradigma kritis, penelitian ini mengungkapkan pemaknaan dan menafsirkan realitas sosial serta berminat melakukan pembongkaran dominasi dari suatu kelompok.

Untuk semakin memudahkan perjalanan memaknai tanda verbal dan nonverbal yang ada pada host Cerdas 5 Menit Episode Sampai Kapan Gaya Dari Utang (Chandra Dewi) dengan tema gaya hidup, maka isi pesan dibagi ke dalam tiga kategori sesuai dengan metode analisis Barthes, yaitu: (1) Pesan Linguistik, yaitu pesan yang dikemas dalam suatu bahasa dengan memaparkan kata dan kalimat yang terdapat pada host Cerdas 5 Menit Episode Sampai Kapan Gaya Dari Utang (Chandra Dewi). (2) Pesan ikonik yang terkodekan yaitu konotasi yang muncul dalam gambar atau visual dan akan berfungsi apabila dikaitkan dengan sistem tanda yang lebih luas. (3) Pesan Ikonik yang tak terkodekan yaitu denotasi harafiah atau pemahaman langsung dari gambar, tanpa mempertimbangkan kode sosial yang lebih luas. Setelah diperoleh paparan panjang mengenai denotasi serta konotasi tanda tersebut, maka dilengkapi dengan ragam sumber data relevan akan membuat hasil penelitian ini semakin lengkap menggambarkan mitologi dan ideologi dari industri talk show media massa.

\section{HASIL DAN PEMBAHASAN}

Gaya talkshow televisi sangat popular dan kekuatan format tersebut terletak pada dialog yang dilakukan oleh host dengan si narasumber ahli. Dalam tayangan yang diambil oleh peneliti sebagai objek penelitian yaitu Cerdas 5 Menit, peran host sedemikian signifikan karena menggiring pembicaraan dari yang sangat sederhana 
yaitu utang yang dekat dengan masyarakat urban, digiring ke paparan berjualan dari Manulife Indonesia yaitu si program asuransi.

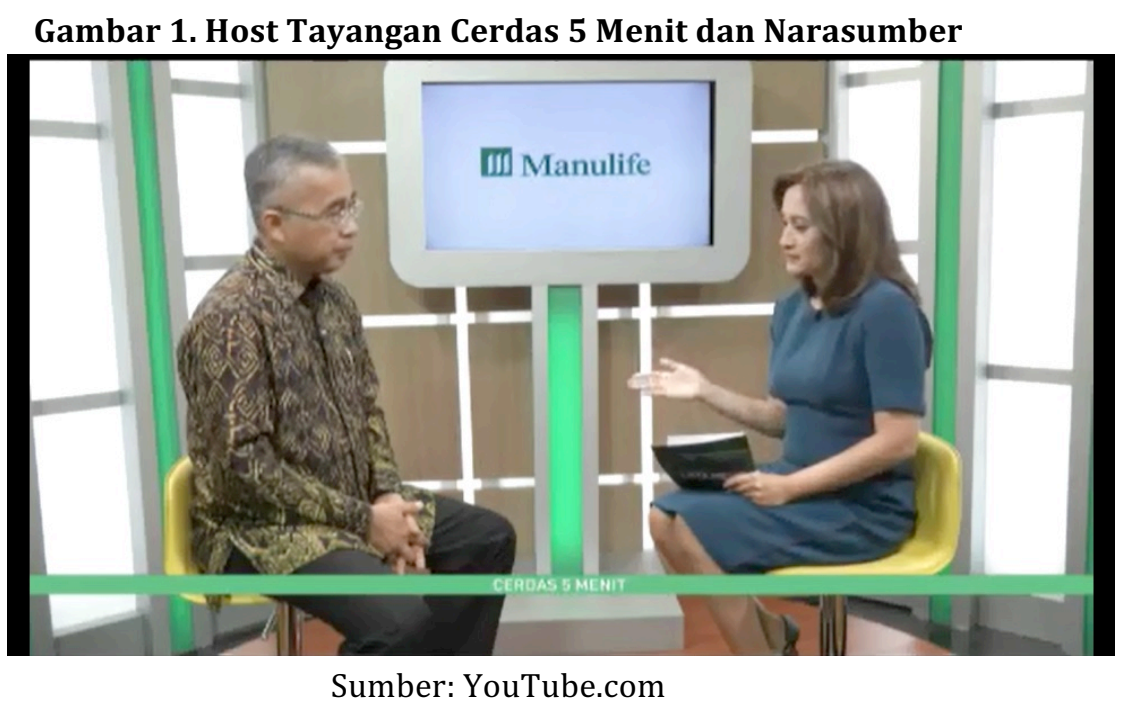

Kekuatan format tersebut terletak pada materi visual dengan passing cepat, mampu melontarkan makna simbolis dan sensasionalitas melalui tampilan visual, juga cara penyampaian pesan yang terkesan informatif, padahal adalah persuasif yang menekankan pengalaman sehari-hari. Walaupun talk show adalah sebuah tayangan yang seringkali meramaikan layar kaca dengan bentuknya yang news ataupun entertainment, kiranya talk show sponsorship dari Manulife Indonesia ini yang memiliki kesan sendiri di masyarakat, bahkan ketika ditayangkan di Channel YouTube Metro TV Manulife pun masih memiliki peminat cukup tinggi, terutama pada episode yang dikaji oleh peneliti.

Paparan yang diberikan oleh Chandra Dewi memiliki pemilihan kata dan bahasa yang wajar serta umum. Tetapi ada suatu cara dan jenis suara dari dirinya yang membuat suatu kalimat berubah menjadi lebih tajam. Sosoknya memiliki perawakan rambut sebahu (ketika peneliti menjadikannya sebagai objek penelitian), dengan mata besar, hidung mancung dan bibir tipis. Senyumnya tipis beriringan dengan gerakan tangan minimal ketika sedang berbicara. Nuansa santai ini yang menjadi pembeda Chandra Dewi dengan host tayangan lainnya dan membuatnya selalu dinanti (Nugroho, 2005, p. 32).

Tujuan awal penelitian ini adalah pembongkaran mitos dan ideologi yang dikandung oleh host Cerdas 5 Menit atau secara spesifik adalah Chandra Dewi. Bukan tanpa alasan, peneliti mencurigai makna terselubung atas tanda verbal dan nonverbal yang disajikan Chandra Dewi ketika membawakan talk show sponsorship Manulife Indonesia dengan tema hutang. Sajian yang tergolong "tidak biasa" di kelasnya ini dipastikan mempunyai cakupan penonton tersendiri, sehingga menjadi ladang hijau bagi Manulife Indonesia untuk menayangkannya di Metro TV (kesesuaian dengan segmentasi). 


\section{Mitologi}

Ideologi dan mitologi tidak bisa dipisahkan. Hal ini terjadi manakala mitologi adalah sebuah wahana dimana ideologi berwujud. Tanda baik yang disengaja atau yang tidak disengaja, menyimpan ideologi yang akhirnya membuat perubahan makna dari dulu sampai sekarang. Hal ini erat kaitannya dengan budaya, konteks, ataupun faktor subjektif lainnya.

Mitologi dan ideologi ditemukan dalam perjalanan mengamati konotasi yang terbentuk dalam teks. Tidak hanya terkandung dalam narasi besar, karya sastra, arsitektur ataupun pahatan dan seni adiluhung lainnya, nyatanya mitologi dan ideologi melekat erat dalam karya remeh temeh seperti program televisi, iklan dan terpaan teks lainnya. Kedua hal ini tidak sengaja dibentuk dan biasanya hanya dalam bentuk gosip semata, hingga akhirnya dibuktikan dalam tindakan nyata, berdasar observasi kasar yang digeneralisasikan dan hidup di masyarakat.

Situasi sosial, budaya dan politik yang ada di sekeliling merupakan wujud bahwa mitologi tidak pernah netral dan selalu ada dalam setiap tanda untuk membantu pembaca mengartikan apa yang dilihat. Mitologi memainkan pesan tertentu yang kadang berbeda sama sekali dengan makna asalnya. Dalam tayangan Cerdas 5 Menit dengan host Chandra Dewi, mitologi dan ideologi terasa kental tergambarkan, baik dalam kaitannya dengan kapasitas Chandra Dewi yang memiliki faktor personal, maupun dominasi acara yang dibawakan.

Menurut Barthes, mitos adalah tipe wicara, sistem komunikasi dan sebuah pesan. Mitos tidak bisa menjadi sebuah objek, konsep atau ide. Mitos adalah bentuk cara penandaan yang identik dengan "perampokan bahasa". Dari sekian banyak tanda verbal dan nonverbal yang dipaparkan secara sengaja dan tidak sengaja oleh Chandra Dewi dalam tayangan ini, peneliti membagi setidaknya 5 (lima) mitologi terbentuk, antara lain:

\section{Transformasi Makna}

Tanda seringkali mengalami pergeseran makna, dimana terdapat perubahan makna dari yang lama menjadi makna baru dengan masih membawa unsur asli makna tersebut. Hal ini kita sebut dengan transformasi makna. Media massa yang sekiranya menjadi medium sekaligus pesan itu sendiri adalah penyebab utama karena dengan terpaannya yang terus menerus, kesadaran baru terbentuk yang tanpa sadar mengganti keyakinan seseorang akan kesadaran lama yang telah terbentuk sebelumnya. Proses yang simultan menandai hal ini, manakala tidak pernah mencapai titik jenuh selama tanda dan makna itu masih tersebar di masyarakat, diiringi kemampuan media massa menyihir audience serta sifatnya yang dinamis walau kadang tidak stabil.

\section{Mitologi Gaya Hidup}

Serangan akan pandangan terhadap media massa bukan hanya menyerang sisi pikiran, melainkan juga dalam kegiatan harian individu yang menontonnya atau tertuang dalam 
gaya hidup. Proses yang terjadi juga cukup unik, yaitu ketika adanya suatu peristiwa atau kejadian yang di masyarakat yang diliput oleh media massa, berdampingan dengan media massa sebagai sebuah acuan untuk melakukan atau tidak melakukan suatu kegiatan; pun menentukan apakah yang akan diperbincangkan untuk hari ini ketika manusia memainkan perannya sebagai makhluk sosial.

Media massa yang di dalamnya mengandung beberapa kepentingan serta keberadaa kaum borjuis memegang peranan penting, manakala budaya tertentu akhirnya terendus oleh media massa, berulang sampai kepada penerima yang terdiri dari berbagai kalangan sosial ekonomi yang menginterpretasikan secara berbeda, baik menyetujui atau justru menolak keberadaan budaya baru tersebut. Makna barupun muncul dalam paparan narasi Chandra Dewi lantaran hal ini berjalan terus menerus beriringan dengan dinamisasi dari masyarakat.

\section{Mitologi Keberpihakan pada Kapitalis}

Media massa, apalagi di sini adalah televisi mengandalkan keberadaan uang dan kekuasaaan sebagai motif dan "motor" utama dalam menjalani bisnis. Perputaran modal berganti dengan untung begitu tinggi, walaupun didapatkan dengan cara yang beresiko, seperti menurunkan kualitas tayangan dan berdampak menggoyang standarisasi di masyarakat. Chandra Dewi di sini sebagai pihak yang memaparkan bahasa verbal serta nonverbal begitu beragam menunjukkan sikap penolakan dan persetujuannya akan dominasi tayangan Cerdas 5 Menit “Epsiode Sampai Kapan Gaya dari Utang?”. Isu yang kebetulan diangkat "menggangu" pemikiran dan nilai pribadinya, maka tidak jarang dengan ia menunjukkan penolakan atas narasi yang ia bawakan sendiri. Tetapi di sisi lain, kemampuan itu terbataskan dengan porsinya yang tidak terlalu dominan, manakala narasumber dalam sebuah talk show dipastikan memiliki lebih banyak peran ketimbang keberadaan si tuan rumah "host".

\section{Mitologi Ego Pribadi}

Netralitas dan profesionalisma yang sejatinya dimiliki oleh seorang penampil di Televisi ternyata tidak selamanya ada dan dapat dipertahankan. Pergeseran makna sering terjadi lantaran erat kaitannya dengan kepentingan personal Chandra Dewi dalam memaparkan narasi. Ada tanda verbal dan nonverbal yang berusaha ia tonjolkan terkait dengan pikiran pribadi yang setuju atau justru menolak keberadaan pemberitaan mengenai "Sampai Kapan Gaya dari Utang". Walaupun dalam posisi duduk, tubuh Chandra Dewi terlihat jelas, menutup diri serta menunjukkan ketidak nyamanan dan kegugupannya dalam menyampaikan narasi yang berujung pada "menjual" jasa proteksi dan investasi.

\section{Mitologi Kepentingan Materialistis}

"Kepentingan" dan media massa saling terikat erat hal ini berujung pada ada hal yang ditonjolkan, juga ada hal dihilangkan. Dilihat bukan hanya dari tayangan atau isu yang diangkat di media massa saja, melainkan aksi ini juga dilancarkan si penampil atau host 
dalam hal ini adalah Chandra Dewi. Ia menjadi boneka yang harus mengikuti "perintah dan arahan" dari crew atau dalam hal ini "atasan" yang memperkerjakannya yaitu Manulife Indonesia. Praktik ini secara nyata tergambarkan dari fisiknya, yang dipilih berdasarkan kriteria cantik ala Indonesia, senyum manis minimali, pilihan warna baju yang menempel pada tubuhnya, cara membawakan narasi, sampai dengan bahasa tubuh yang diekspresikan. Semua ini tidak terlepas dari usaha Manulife Indonesia dalam mengonstruksi nilai dominan yang dianggap benar dan wajib menjadi nilai penting dan diikuti oleh masyarakat. Menjadi trendsetter dan kerap membawa isu relevan dan "kekinian" adalah hal yang dicita-citakan oleh tayangan Cerdas 5 Menit.

Dua mitologi yang begitu dominan dalam pemaparan ini antara lain Mitologi Ego Pribadi dan Mitologi Transformasi Makna yang menjadi kunci dalam perubahan makna dari tanda verbal dan non verbal pemaparan Host Cerdas 5 Menit Chandra Dewi.

Tabel 1. Pemetaan Mitologi

\begin{tabular}{|c|c|c|c|}
\hline Tanda & Part & Makna Baru & Mitologi \\
\hline \multirow[t]{3}{*}{$\begin{array}{l}\text { Penekanan } \\
\text { Kata }\end{array}$} & Opening & $\begin{array}{l}\text { Munafik (pada kata "BERUTANG" dan } \\
\text { "CERDAS } 5 \text { MENIT") }\end{array}$ & \multirow[t]{3}{*}{$\begin{array}{l}\text { Transformasi } \\
\text { Makna }\end{array}$} \\
\hline & Opening & $\begin{array}{l}\text { Pergumulan dan Penolakan (pada kata } \\
\text { "CERDAS } 5 \text { MENIT") }\end{array}$ & \\
\hline & $\begin{array}{l}\text { Pertanyaan } \\
\text { I }\end{array}$ & $\begin{array}{l}\text { Sindiran (pada kata "PENGELOLAAN } \\
\text { KEUANGAN") }\end{array}$ & \\
\hline $\begin{array}{l}\text { Perlambatan } \\
\text { Kata }\end{array}$ & Opening & $\begin{array}{l}\text { Pergumulan dan Penolakan (pada kata } \\
\text { "CERDAS } 5 \text { MENIT") }\end{array}$ & Ego Pribadi \\
\hline $\begin{array}{l}\text { Percepatan } \\
\text { Kata }\end{array}$ & $\begin{array}{l}\text { Pertanyaan } \\
\text { I }\end{array}$ & $\begin{array}{l}\text { Penegasan (pada kata "PENGELOLAAN } \\
\text { KEUANGAN") }\end{array}$ & $\begin{array}{l}\text { Transformasi } \\
\text { Makna }\end{array}$ \\
\hline \multirow[t]{2}{*}{$\begin{array}{l}\text { Anggukan } \\
\text { Kepala }\end{array}$} & Opening & $\begin{array}{l}\text { Penolakan atas dominasi (pada kata } \\
\text { "BERUTANG") }\end{array}$ & \multirow[t]{2}{*}{$\begin{array}{l}\text { Transformasi } \\
\text { Makna }\end{array}$} \\
\hline & $\begin{array}{l}\text { Pertanyaan } \\
\text { I }\end{array}$ & $\begin{array}{l}\text { Usaha Menyadarkan (pada kata "CERDAS } 5 \\
\text { MENIT") }\end{array}$ & \\
\hline \multirow[t]{2}{*}{$\begin{array}{l}\text { Memiringkan } \\
\text { Kepala }\end{array}$} & $\begin{array}{l}\text { Pertanyaan } \\
\text { V }\end{array}$ & $\begin{array}{l}\text { Penolakan atas dominasi (pada kata } \\
\text { "PROTEKSI DAN INVESTASI") }\end{array}$ & \multirow[t]{2}{*}{ Ego Pribadi } \\
\hline & $\begin{array}{l}\text { Pertanyaan } \\
\text { I }\end{array}$ & $\begin{array}{l}\text { Kedengkian dan ketidaksukaan (pada kata } \\
\text { "“BERUTANG”) }\end{array}$ & \\
\hline $\begin{array}{l}\text { Mata } \\
\text { Membelalak }\end{array}$ & $\begin{array}{l}\text { Pertanyaan } \\
\text { V }\end{array}$ & $\begin{array}{l}\text { Penolakan atas dominasi (pada kata } \\
\text { "PROTEKSI DAN INVESTASI) }\end{array}$ & $\begin{array}{l}\text { Transformasi } \\
\text { Makna }\end{array}$ \\
\hline Lirikan Mata & $\begin{array}{l}\text { Pertanyaan } \\
\text { V }\end{array}$ & $\begin{array}{l}\text { Keenganan Pembahasan (pada kata } \\
\text { “PROTEKSI DAN INVESTASI) }\end{array}$ & Pribadi $^{\text {Ego }}$ \\
\hline Senyuman & Opening & $\begin{array}{l}\text { Demi Keuntungan bukan Ketulusan (pada } \\
\text { kata "CERDAS } 5 \text { MENIT") }\end{array}$ & Ego Pribadi \\
\hline $\begin{array}{l}\text { Tangan } \\
\text { Menutup }\end{array}$ & $\begin{array}{l}\text { Pertanyaan } \\
\text { V }\end{array}$ & $\begin{array}{l}\text { Perintah (pada kata “PROTEKSI DAN } \\
\text { INVESTASI) }\end{array}$ & $\begin{array}{l}\text { Transformasi } \\
\text { Makna }\end{array}$ \\
\hline $\begin{array}{l}\text { Tangan } \\
\text { Menelungkup }\end{array}$ & $\begin{array}{l}\text { Pertanyaan } \\
\text { V }\end{array}$ & $\begin{array}{l}\text { Dominasi dan Perintah (pada kata } \\
\text { "PROTEKSI DAN INVESTASI) }\end{array}$ & $\begin{array}{l}\text { Transformasi } \\
\text { Makna }\end{array}$ \\
\hline
\end{tabular}




\begin{tabular}{|c|c|c|c|}
\hline $\begin{array}{l}\text { Tangan } \\
\text { Menunjuk }\end{array}$ & Opening & $\begin{array}{l}\text { Keinginan untuk membuka mata dari } \\
\text { pemirsa (pada kata "BERUTANG") }\end{array}$ & $\begin{array}{l}\text { Transformasi } \\
\text { Makna }\end{array}$ \\
\hline
\end{tabular}

\section{Mitologi Transformasi Makna}

Senyum adalah identitas yang dibentuk dengan bibir, gigi, dan mulut yang melengkung, yang menjadi pembeda dirinya dengan orang lain, walaupun pada anak kembar identik sekalipun yang memiliki kesamaan fisik dan wajah. Bentuk wajah dari Chandra Dewi yang cantik versi Indonesia semakin manis ketika disunggingkan senyumannya yang tipis. Senyuman yang kiranya (biasanya) menunjukkan suasana hati dalam keadaan bersukacita, menunjukkan bahwa senyuman juga dapat membuat orang lain merasa senang, juga hati terasa nyaman. Hal ini berkaitan erat dengan makna suatu senyuman yang bukan hanya menempel atau berimbas pada sosok diri yang tersenyum, melainkan juga pada orang lain.

Sebuah senyuman dapat dirasakan, apakah benar tulus atau sekedar ada, walaupun ditampilkan oleh penampil di media massa. Senyuman dapat menjadi topeng belaka, lantaran hal ini yang akan membuat penampil mendapatkan uang.

Dianggap sebagai wujud persetujuan akan suatu hal, senyuman juga berarti wujud penolakan atau sindiran. Hal ini biasanya berkaitan dengan senyum yang dibuat-buat. Hal ini biasanya diikuti sorot mata tajam, bentuk mata membelalak, serta bentuk alis yang mengkerut (menyatu), yang menunjukkan penolakan yang bergejolak dalam diri. Atas nama kesetiaan pada pekerjaan dan profesionalitas, senyum tersebut dipaparkan. Senyuman yang mengalami pergeseran makna tidak ubahnya bentuk sindiran yang diberikan si penampil terhadap sajian Cerdas 5 menit yang menurutnya aneh, tidak ia sukai dan terpaksa ia bawakan

\section{Mitologi Gaya Hidup}

Fashion adalah arena bermain bebas para pekerja kreatif yang mendukung kemunculan lapangan kerja bagi banyak orang. Sebut saja perancang busana, photographer, perias wajah dan rambut, model, penjahit, konveksi, sampai dengan pengecer. Setiap elemen ini saling membutuhkan, membangun lingkaran penuh makna yang tidak boleh terputus. Selain itu, Fashion juga memberikan keuntungan bagi lokasi tempat toko Fashion berada (mall, toko baju, aksesoris, dan lainnya).

Walaupun identik dengan aksesoris dan kelengkapan yang mahal, fashion memberikan keuntungan bukan hanya untuk kalangan kelas atas saja, nyatanya Fashion juga bagi kalangan kelas menengah ke bawah yang mampu menjual barang tiruan kelas atas dengan harga murah dan terjangkau sehingga dapat dinikmati oleh semua kalangan. Lebih dalam lagi, mereka yang bermain dalam ranah dunia online (memunculkan situssitus dan pihak-pihak tertentu yang bekerja dalam pengoperasian dunia siber) semakin kreatif dalam menjajakan dagangannnya. 
Fashion menarik semuanya membaur menjadi satu tanpa bisa dipisahkan mana yang berasal dari gaya lama, dan mana yang berasal dari gaya baru. Semua bercampur baur menjadi satu membentuk suatu gaya kontemporer yang dianggap sebagai gaya terkini. Walaupun terkadang, mereka yang memiliki ciri dan perbedaan tersendiri, justru yang lebih mudah dikenal adalah kreatifitas dan ide menjadi kunci utama untuk bertahan dalam dunia yang selalu berubah. Suatu model tidak bisa dikatakan lagi hanya menjadi ciri dari periode tertentu seperti 60an, 70an, dan sebagainya.

Fashion identik dengan kebebasan dan keleluasaan tanpa perlu takut akan ada hukuman sebagai sangsinya. Kreatifitas menjadi hal yang dijunjung tinggi dalam dunia Fashion, dalam kaitannya dengan perancang, penjual, ataupun pengguna yang harus mampu melakukan mix and match. Dan sekali lagi ditekankan bahwa fashion bukan hanya masalah periode waktu, tetapi perpaduan gaya yang berasal dari luar dan dalam negeri juga sudah bercampur.

\section{Mitologi Keberpihakan}

Pertama, bentuk dan bahasa tubuh. Chandra Dewi yang dalam episode kali ini mengangkat isu remeh temeh yang terjadi dalam kehidupan harian, bukan digadang sebagai selebriti kelas A, tetapi sebagai standard wanita high class. Wajahnya cantik dan khas, menjadi salah satu elemen untuk mendukung audience untuk menontonnya. Zaman dahulu mungkin belum terklasifikasi nyata, siapa dan bagaimana sosok yang cantik dan jelek. Tetapi sekarang, dengan adanya media massa, klasifikasi itu terlihat jelas. Sebut saja nama seperti Raline Shah, Raisa dan Sophia Latjuba yang memiliki kesamaan, yaitu langsing dan proporsional. Hal ini membuat mereka dikatakan menarik, rupawan, cantik. Mereka jauh dari kesan berat badan berlebih, gemuk, hitam, dan berantakan yang akhirnya berujung pada anggapan sebagai wanita kurang menarik dan kurang cantik.

Paparan semacam ini berkaita erat dengan kebutuhan produk dan atau pengiklan untuk mendapatkan pembeli di lapangan. Standarisasi ini mendukung seorang wanita untuk ingin memiliki kulit bersih bisa menggunakan produk $\mathrm{X}$, ingin memiliki tubuh tinggi menggunakan suplemen Y, dan seterusnya. Praktik ini tidak lebih dari membodohi publik untuk membuat produk-produk tersebut terus berkembang biak, dan akhirnya masyarakat hidup bukan dengan kehendak bebasnya sendiri, melainkan dibentuk oleh mereka yang berkepentingan mengeruk uang.

Dari wajah yang sempurna dengan tubuh yang ideal, pemaknaan yang berujung pada mitologi keberpihakan adalah bagaimana gaya duduk dan tangan Chandra Dewi begitu kaku dan minimal gerakan di awal acara tersebut baru dimulai. Untungnya keadaan ini akhirnya berubah cari, dimana tangan yang sebelumnya berada di depan tubuh sebagai bentuk anti serangan sekaligus menyembunyikan kegugupan, akhirnya berubah menjadi bahasa tubuh luwes dan bebas di pertengahan. Hal inipun turut diikuti oleh 
ekspresi muka santai, lantaran sudah bisa menempatkan diri pada posisi yang pas dalam narasi Cerdas 5 Menit tersebut.

Kedua, Fashion. Pandangan yang akhirnya disadari sebagai sebuah realitas pada zaman sekarang menekankan bahwa wanita cantik layaknya memiliki postur tubuh ideal, kulit putih, wajah full dengan make up hingga pakaian yang digunakan "harus" mahal. Praktik ini juga tanpa sadar tergambar dalam penggunaan dress oleh Chandra Dewi. Sosoknya menggunakan baju formal (dress) seperti mengangkat standarisasi masyarakat bahwa wanita elegan adalah yang demikian. Walaupun untuk kegiatan bincang-bincang saja, baju yang demikian dianggap wajar, lantaran tayangan Cerdas 5 Menit mengudara setiap hari. Dress glamour telah kehilangan unsur "WAH" dan menjadi hal biasa.

Penyamarataan selera dan standard dalam melihat suatu hal adalah baik atau buruk adalah wujud dari pemaksaan. Fashion adalah wujud pemaksaan tersebut. Hal ini tidak dirasakan oleh para pecintanya yang berasal dari kalangan elite, ataupun pengagumnya yang berasal dari kalangan pinggiran. Fashion sendiri yang memunculkan kotak-kotak tak kasat mata terkait mana penampilan in dan yang kuno, sosok yang modis dan yang konvensional, ataupun siapa yang tampan dan cantik dengan yang jelek dan tidak menarik.

Dengan paparan fashion yang ditampilkan, Program Cerdas 5 Menit !nsert akhirnya memaparkan "inilah gaya yang seharusnya dimiliki oleh selebriti ataupun rakyat biasa, jika ingin tampil sempurna". Metro TV sebagai tempat bernanung program tersebut, dimana Chandra Dewi juga adalah "Alat" di sana, mewujudkan keadaan di layar kaca adalah lumrah untuk kehidupan sehari-hari.

Akhirnya, manusia membuat standar keberhasilan dinilai dari bagaimana ketika ia mampu membeli aksen fashion tertentu dengan harga yang menjulang tinggi, bukan menjadi kelas yang hanya berdandan ala kadarnya. Fashion memberikan petunjuk yang memaksa mengenai gaya mana yang harus atau wajib ditiru demi mengikuti perkembangan zaman. Hal ini dibuktikan dengan semakin banyaknya remaja ataupun pecinta fashion yang seringkali salah gaya atau salah kostum atau salah tempat lantaran memaksakan suatu fashion tertentu yang sebenarnya tidak cocok dikenakan oleh dirinya.

\section{Mitologi Ego Pribadi}

Bentuk dan Bahasa Tubuh Chandra Dewi tampil apik dengan balutan baju mewah, pulasan make up lekat, rambut tertata rapi serta wajah yang cantik. Hal ini menunjukkan bahwa ia memiliki standarisasi sendiri, sekaligus dibentuk oleh media massa tempat dimana ia "bekerja". Dalam keadaan baju dengan model tertutup, disampaikan oleh Freud bahwa sesuatu yang ditutupi justru menimbulkan keingintahuan, nyatanya hal itu juga yang melekat dalam penampilan Chandra Dewi. 
Cenderung minimalis dalam pemaparan tanda bersanding dengan posisi duduknya yang "kalem", nyatanya gerakan tangan dan penekanan kata tetap mampu menunjukkan sebenarnya apa yang ingin ia sajikan. Bukan hanya dalam urusan fisik, melainkan Chandra Dewi tetap memilih hal-hal tertentu seperti membangun menara tangan dan tudingan demi menutupi rasa gugup dan ketidaksukaannya akan topik yang sedang ia bahas. Hal ini berjalan beriringan dengan ketidakmampuan Chandra Dewi menahan ekspresi penolakan terhadap kata seperti "CERDAS", "PROTEKSI", dan "INVESTASI".

\section{Mitologi Kepentingan Materialistis}

Pertama, Fashion (Dress Hijau Tua). Pakaian yang dikenakan oleh Chandra Dewi menunjukkan program yang dibawakan adalah adalah bukan main-main, walaupun materi yang ditekankan adalah hal paling dekat dengan kehidupan pribadi. Hal ini juga menunjukkan bagaimana Chandra Dewi dalam kodratnya sebagai seorang wanita yang memakai rok, tetapi mampu membawakan materi tersebut dengan sangat sempurna, walau berhadapan dengan narasumber laki-laki serta paparan keuangan yang "rumit" biasanya lebih diminati oleh seorang laki-laki. Menghilangkan stigma dan pandangan sebagai sosok yang "lebih banyak utang dan ketidakmampuan mengontrol keuangan", wanita di sini disetarakan dengan pria.

Lebih jauh pakaian dengan nuansa utama hijau gelap ini sejalan dengan sponsor atau penyelenggara tayangan Cerdas 5 Menit yaitu Manulife Indonesia yang mencoba megambil filosofi bahwa perusahaanya yang nota bene berwarna hijau adalah "bantuan" dalam kesulitan yang artinya memiliki kepercayaan dan "hidup" walau disandingkan dengan ketidakamanan.

Pakaian yang berwarna gelap dengan potongan begitu cantik, tanpa sadar menunjukkan bahwa ia tengah membangun "benteng" supaya terbebas dari serangan luar yang datang mengintervensi. Ia menjadi pribadi yang naif, dan harus membawakan paparan tersebut walau mungkin bertentangan dengan nilai pribadinya, semata-mata agar kepentingan materialistis tayangan terpenuhi.

Kedua, Media Massa. Televisi dan internet kini memiliki peminat yang tidak jauh berbeda manakala keberadaan media daring belum bisa mengalahkan keinginan dan kebutuhan pemilik iklan untuk tetap memasang produknya di media elektronik audio visual yaitu televisi. Tayangan Cerdas 5 Menit di sini mengambil kedua platform dengan sangat maksimal, manakala ia menampilkan pada stasiun TV Metro TV, sekaligus membuat tayangan terdokumentasi dengan baik pada kanal YouTube.

Hal ini tidak dapat mengelakkan keberadaan media massa sebagai ajang pengerukan uang oleh kalangan elite dan konglomerat media massa. Tema yang diambil juga sangat dekat dengan warga perkotaan, didukung dengan gambar-gambar yang dimasukkan yaitu pusat perbelanjaan dengan segala kemeriahannya. Hal ini seakan tidak 
mempedulikan sama sekali kalangan miskin yang masih jauh dari budaya berbelanja atau berutang di pusat perbelanjaan.

Utang konsumtif dalam tayangan ini menjadi begitu dominan, dengan alasan menyatakan realitas yang terjadi, tetapi nyatanya hanya memberikan kebobrokan warga kota dalam menjaga keuangannya. Audience yang menjadi penonton pasif, pada akhirnya menerima, padahal yang dirujuk oleh tayangan ini adalah kemampuannya untuk menjual jasa proteksi dan investasi dari perusahaan Manulife Indonesia.

Ketiga, Elemen Gambar. Dalam tampilan Cerdas 5 Menit, yang dijadikan subjek utama bukanlah keberadaan Chandra Dewi sebagai seorang host. Hal ini kiranya sejalan dengan prinsip talk show, dimana host adalah sebagai perantara topik saja, bukan pemberi informasi. Keadaan demikian semakin tergambar nyata lantaran pemilihan warna yang ada pada studio adalah mengutamakan warna cerah (putih dan hijau sejalan dengan nuansa warna Manulife Indonesia), berbanding terbalik dengan tampilan Chandra Dewi yang mengenakan baju berwarna gelap yang akhirnya ia "tertutup" dan tidak bersinar.

Dibandingkan dengan keberadaan host, set memegang peranan lebih penting. Tetapi ketika dibandingkanlah keberadaan set studio dengan konten atau tema yang diangkat, maka tema yang diangkatlah memegang peranan paling utama dan dianggap penting dari talk show tersebut. Hal ini bukan tanpa sebab manakala set putih tersebut hanya memiliki aksen hijau berbentuk garis yang nota bene tidak terlalu menjual apalagi ketika tayang di stasiun TV sekelas Metro TV, dengan sponsor utama yaitu Manulife, sebuah perusahaan asuransi terkenal dan sepak terjang sudah lama di Indonesia.

Terakhir, penggunaan televisi yang bertuliskan Manulife Indonesia dengan gaya dan ukuran tulisan demikian menunjukkan bagaimana branding begitu penting dalam membuat masyarakat memahami bahkan mau menggunakan produk jasa tersebut. Tampilan tersebut adalah sederhana tetapi mau tidak mau terlihat ketika shot sedang mengarah pada 2 orang yaitu host dan narasumber. Dari setting studio, terlihat ketidakinginan dari Tim Cerdas 5 Menit memberikan kesempatan untuk Chandra Dewi sebagai host, tampil utuh atau dominan. Gempuran nama sponsor dan nama program terus menerus dilakukan tanpa perlu diucapkan oleh narasi menjadi jauh lebih penting, walaupun tidak diulang secara kata-kata dan gerakan.

\section{Ideologi}

Zaman sekarang, kata "media massa" tidak berdiri sendiri melainkan disandingkan dengan kata "industri". Bukan tanpa sebab, manakala dahulu tujuan media massa adalah ajang untuk menyampaikan informasi, edukasi dan hiburan, kini bergeser jauh menjadi arena bermain bagi pemilik modal demi meraup keuntungan. Siapa kawan, siapa lawan yang dahulu bisa terbedakan sempurna, kini tergerus dan baur menjadi satu lantaran tujuan utama media massa kini semata-mata mendapatkan tempat di hari, 
hati dan pikiran audience sehingga berujung pada pembelian atau peneguhan keputusan akan kepercayaan suatu program. Produksi, distribusi dan konsumsi adalah siklus yang harus dijalani oleh media massa. Hal ini juga yang menyebabkan konstruksi realitas yang dianggap benar dan disajikan kepada masyarakat sehingga menjadi agenda perbincangan publik adalah lumrah. Dari mana hal tersebut berasal? Siapa penctusnya? Apa tujuannya? Ideologi adalah jawabannya.

Peraturan hukum yang mengikat ataupun praktik kenegaraan yang mementingkan sanksi atau penghargaan adalah kilasan singkat ideologi yang diketahui secara umum. Nyatanya, ideologi melekat dalam karya sastra dan seni yang bernilai tinggi, hal-hal yang berwujud dan tidak berwujud (pikiran, tindakan, perilaku, budaya dan sebagainya) pada diri seorang manusia. Bahkan ketika manusia itu mengatakan ia tidak memiliki ideologi, di sanalah ideologi itu berwujud lantaran ideologi melingkupi manusia dan berada dalam diri manusia, tanpa terelakkan.

Bila halnya manusia dengan segala kelebihan dan keterbatasannya memiliki ideologi, apalagi sebuah media massa yang memang dianggap sebagai suatu media, tetapi jangan dilupakan bahwa ia tidak berjalan sendiri melainkan mencakup ratusan kepala di dalamnya. Dalam wujud yang lebih besar dan tidak sadar, ideologi mempengaruhi pihak yang bersinggungan atau terlibat, baik pekerja, audience yang ditargetkan ataupun yang tidak, bahkan justru yang membenci media tersebut.

Ideologi pada televisi yang memiliki kelebihan penyerangan indra penglihatan dan pendengaran, mampu mempengaruhi orang lain supaya berbuat sesuai dengan apa yang diinginkan, walau secara pribadi sebenarnya tidak ingin demikian. Masyarakat tanpa sadar dipaksa menikmati apapun yang disajikan oleh kotak ajaib bernama televisi, dan mendewakan siapapun yang ada di dalamnya sebagai sosok yang wajib dipuja dengan ketampanan dan kecantikan ataupun kepintarannya. Pembentukan standarisasi tertentu layaknya hukum wajib audience untuk mematuhi dan bila tidak, maka akan dianggap aneh.

Talk show sebagai salah satu sajian yang kuat dan disukai lantaran paparan ringan dan informasi menarik di dalamnya, memuaskan keinginan dasar manusia yang selalu ingin mengetahui lebih banyak apalagi isu yang lekat dengan kehidupan pribadi sehari-hari. Walaupun pada akhirnya ada batas privasi tersendiri yang dilanggar dan melenceng, hal itu didiamkan saja karena ilmu yang didapatkanpun sebanding.

Tanda verbal dan nonverbal host Cerdas 5 Menit (Chandra Dewi) menjadi objek penelitian kali ini. Hal ini sejalan dengan tanda yang diberikan oleh host, memiliki ragam makna yang menunjukkan persetujuan bahkan penolakan akan naras yang ia bawakan. Gempuran dominasi yang diberikan kepada host mendatangkan ekspresi tersendiri dalam setiap kata yang diucapkan dan tubuh yang digerakkan sehingga tidak 
jarang timbul makna baru akan sebuah tanda yang erat kaitannya dengan keberadaan ideologi di balik sosok Chandra Dewi.

Ideologi utama yang akhirnya tergambar jelas dan mampu disoroti peneliti adalah ideologi kapitalisme. Pemaparan berujung pemaknaan Chandra Dewi dalam pemilihan kata dan bahasa, penampilan serta gestur merujuk praktik menumbuhkembangkan keberadaan kaum elite media massa, atau dalam hal ini adalah sponsor tayangan talk show Cerdas 5 Menit, yaitu Manulife Indonesia. Dengan cara yang halus dan tepat, ia mengirimkan pesan berisi informasi yang akhirnya dianggap sebagai berita baru di masyarakat, tetapi berujung pada paparan mengenai pentingnya proteksi dan investasi yang merupakan produk jasa Manulife Indonesia.

"Utang" sebagai topik bahasan merupakan ide cemerlang karena faktor kedekatan dengan keseharian audience baik kelas atas, menengah dan bawah. Walaupun Metro TV adalah tayangan untuk kelas atas (karena mayoritas sajiannya adalah berita) dan tayangan ini juga menyoroti hal-hal yang berkaitan dengan kelas atas, esensi utama televisi yang mampu menjangkau ragam kalangan tidak boleh dilupakan. Ada seni khusus dalam "BERUTANG" sehingga dibicarakan. "Utang" yang dahulu dianggap sebagai suatu kesalahan dan hal terkahir yang dilakukan ketika "kepepet", beralih menjadi gaya hidup yang lumrah bahkan "keren". Hal ini dibuktikan dengan semakin banyaknya layanan dunia nyata maupun platform khusus yang memberikan pinjaman, dengan cara bayar yang cenderung dianggap memudahkan.

Bila disadari, segala bentuk utang (yang semakin mudah dalam pengajuan, ataupun semakin mudah dalam pembayaran) mengantar masyarakat pada pola hidup yang konsumtif. Seperti dipaparkan di atas, konsumtif yang paling banyak menerpa adalah di sisi sandang (pakaian) dan pangan (makanan). Pada akhirnya "Konsumtif" yang merajalela di masyarakat mengalami pergeseran makna ketika bersinggungan dengan kegiatan hari-hari yaitu bukan lagi memakai hasil orang lain, tetapi lebih ke sisi kewajiban menggunakan barang tersebut bukan karena keinginan.

Terpaan isu pribadi yang semakin sering dibahas di ranah publik, menghilangkan unsur privasi. Media massa mengambil peran yang tidak sedikit di sana. Terpaan semacam ini menjadi wujud arus kapitalis yang menyerang masyarakat pecinta media massa. Mereka dihadapkan dengan kenyataan bahwa ranah pribadi adalah hal yang tidak lagi tabu karena setiap orang berhak untuk mengetahui apa yang terjadi dengan orang lain, untuk hal yang baik atau buruk sekalipun.

Keberadaan ranah privat atau pribadi sejatinya hilang, tidak dipungkiri karena banyak public figure di luar sana juga tidak menganggap ranah privat itu masih ada. Saling serang dan kritik, bahkan menuding dan menggugat memang hanya berujung pada mencari sensasi. Lantas, bila sosok public figure saja rela "seluruh" dirinya menjadi konsumsi publik, apa hak masyarakat biasa untuk menolak hal itu terjadi. Kehidupan 
intim rumah tangga yang sebegitu sakralnya bisa berubah menjadi guyonan seluruh dunia (lantaran tayang di YouTube), apalagi semata tentang utang?

Bukan hanya topik, keberadaan Chandra Dewi sebagai seorang host yang bernuansa kapitalistik. Dari fisiknya, ia memiliki tubuh yang indah dan proporsional untuk ukuran wanita Indonesia. Wajahnya cantik, bebas dari jerawat mengenakan pakaian yang menunjukkan kemewahan dan anggun.

Rambut dicat berwarna menunjukkan gayanya yang kekinian. Fashion yang ia gunakan hingga cara duduknya menunjukkan dirinya smart dan tidak tersentuh oleh siapapun. Tetapi di samping itu, arogansi dan proteksi diri yang muncul dari gerakan tubuh dan kata yang ia ucapkan menunjukkan keinginan Chandra Dewi untuk dipandang dominan dalam pembahasan "Sampai Kapan Gaya dari Utang". Tidak ada asesoris yang menempel pada tubuh Chandra Dewi, tetapi setiap elemen yang melekat dalam tubuhnya dibentuk bernilai yang mencerminkan kelompok kelas atas tertentu. Hal ini mengukuhkan dirinya sebagai sosok yang "tidak terjangkau".

Chandra Dewi yang dalam hal ini dianalogikan peneliti sebagai boneka kapitalis juga tergambar dalam kata-kata dan bahasa tubuhnya. Tanda nonverbal yang paling sering ia tampilkan adalah anggukan kepala dengan ragam makna, mulai dari persetujuan, penolakan, ekspresi kebahagiaan sampai dengan sindiran. Dilihat dari pemaknaan dasar atau tingkat pertama maka anggukan ini mengandung unsur pembelaan narasi yang ia bawakan. Jika ditelusuri lebih jauh dengan pembacaan gabungan tanda nonverbal lainnya, anggukan justru merujuk pada keengganan Chandra Dewi dalam menyampaikan narasi yang menyangkut "Utang", "Proteksi" dan "Investasi".

Apa yang diberikan oleh televisi adalah bentukan realitas yang telah dirubah sedemikian rupa sehingga hanya menampilkan sisi-sisi tertentu yang sesuai dengan ideologi media itu sendiri. Ideologi kapitalis ini berwujud setidaknya dalam lima mitologi kunci yang telah dibahas sebelumnya. Pengiklan di sini bukan lagi sebagai pemberi modal, melainkan memainkan perannya sendiri sebagai isi dari program bincang-bincang menarik yang enggan dilewatkan oleh pecintanya.

Tidak berhenti dalam pendapatan maksimal, rupanya praktik ini juga menghegemoni penerima akan ide yang disajikan (utang adalah wajar, uang bisa dicari, asuransi adalah kunci sukses). Penyerangan ini berlangsung secara terus menerus, sehingga penerimanya tidak sadar bahwa ia sedang dalam posisi tidak aman terhadap paparan media massa.

Praktik yang dilakukan Cerdas 5 Menit begitu halus, tidak secara langsung mengajak audience untuk menjadi pengikutnya, melainkan menghubungkan tema yang terkesan biasa saja ini dengan kehidupan sehari-hari. Tidak bisa dilupakan bagaiamana salah 
satu unsur berita yaitu proximity (kedekatan) menjadi kunci untuk masuk ke dalam hati audience.

Penting diingat bahwa setiap elemen dalam tubuh dan gaya bicara ataupun kata yang diucapkan oleh host adalah serangan. Bagaimana gaya duduk, gaya bahasa Chandra Dewi dan lantunan nada dalam kata yang begitu indah melekat dalam benak penontonnya. Serangan-serangan halus semacam ini yang tidak bisa dihindari oleh masyarakat yang terlanjur menyaksikan dan menikmatinya.

Bukan lagi terpaan jarum hipodemik yang mengambil peran di sana, melainkan terpaan jarum konglomerat yang membuat terjadinya keadaan demikian. Masyarakat yang tidak lagi berada dalam posisi pasif melainkan aktif, demikian "bodoh" di hadapan sajian televisi karena serangan televisi dilancarkan dalam bentuk bincang-bincang harian yang dekat dan biasa dialami oleh pemirsa.

Semua nilai dari budaya barat, yang positif dan negatif diterima oleh pemirsa televisi, baru kemudian disesuaikan dengan konteks ke-Indonesia-an. Tetapi kemampuan menyesuaikan itu yang tidak dimiliki oleh semua orang dalam menghadapi serangan televisi yang hadir terus menerus. Tayangan televisi memberikan kesadaran baru sementara si penerima tidak sadar, pola pikir dan tindakannya telah dibentuk oleh keberadaaan tayangan tersebut. Kejadian semacam ini terus berulang tidak pernah jenuh sampai akhirnya menjadi kesadaran baru yang lebih diyakini kebenarannya oleh si pemirsa televisi.

\section{SIMPULAN}

Melakukan proses pemaknaan dengan pisau analisis Roland Barthes, peneliti melihat banyak pergeseran makna yang terjadi dalam tayangan Cerdas 5 Menit Episode Sampai Kapan Gaya dari Utang, baik dari segi tanda verbal dan nonverbal host Chandra Dewi. Hal itu tidak lepas dari ideologi yang ada di dalam diri Chandra Dewi, berjalan beriringan dengan ideologi dari Sponsor yaitu Manulife Indonesia. Maka beberapa hasil yang didapatkan dari penelitian ini antara lain:

Nilai yang dipegang teguh oleh Chandra Dewi melahirkan mitologi ego pribadi. Dalam hal ini, dominasi yang menyerang Chandra Dewi ditolak secara mentah ditunjukkan dalam ekspresi dan bahasa tubuhnya ketika menyampaikan narasi. Ia memberikan penekanan dan perlambatan dan percepatan kata tertentu, kemudian menggerakan bagian tubuh yang lain sebagai wujud kepasrahan dan penolakan dominasi. Hal ini yang secara konsisten Chandra Dewi lakukan hingga akhirnya membawa ia pada suatu sikap "bertahan" dengan cara tertentu. 
Mitologi berjalan sesuai perkembangan dan kekayaan dari ideologi kapitalis, antara lain ego pribadi, kepentingan materialistis, gaya hidup, keberpihakan, dan transformasi makna. Semua mitologi merujuk pada pergeseran makna akibat keinginan kaum kapitalis untuk semakin menambah pundi-pundi uang dan kekuasaannya dengan cara yang nota bene menyerang audience dalam tayangan yang akhirnya dianggap sebagai sebuah tayangan biasa, tetapi nyatanya berjualan semata.

Sosok Chandra Dewi dalam tayangan ini tidak ubahnya sebagai sosok yang merupakan boneka demi kepentingan penyampaian narasi semata dari Manulife Indonesia. Dengan naskah yang sudah disusun sebelumnya, yang ditampilkan dan ditonjolkan di sini bukanlah dirinya, melainkan sebatas perangkat konstruksi professional. Hal ini tersaji jelas dalam fashion yang melekat pada tubuhnya, kata-kata yang ia ucapkan, dan ekspresi yang dipapakan.

Audience adalah awal dan akhir yang menjadi subjek sekaligus objek dalam paparan Manulife Indonesia. Keberadaan tayangan ini tidak terlepas sebagai senjata penarik pengiklan. Maka tidak dipungkiri bahwa komodifikasi dan standarisasi menjadi hal yang dibudidayakan. Gempuran kepentingan kapitalis media dan kapitalis produk, terutama yang berkaitan dengan proteksi dan investasi berjaya dalam tayangan berdurasi singkat ini dalam membangun kesadaran dalam benak audience bahwa informasi tersebut adalah berguna dan layak diikuti.

Setelah perjalanan pembacaan tanda dari sosok host Chandra Dewi dalam Cerdas 5 Menit Episode Sampai Kapan Gaya Dari Utang, peneliti berharap hasil penelitian ini memberikan kontribusi maksimal terhadap perkembangan akademis dan praktis. Beberapa saran yang bisa disajikan oleh peneliti terkait penelitian Mitologi Host Cerdas 5 Menit Manulife Indonesia adalah:

Secara akademis, penelitian ini memberi perkembangan untuk dunia televisi supaya menyajikan tayangan edukatif yang bukan melulu berorientasi pada uang atau keuntungan perusahaan. Kurangnya perhatian dari lembaga berwenang dalam mengurus masalah penyiaran dapat menjadi angin segar bagi pihak pemberdaya tayangan untuk melancarkan serangan-serangan halus kepada audience. Hal ini perlahan mengikis kesadaran masyarakat menjadi kesadaran palsu semata. Penelitian yang terkait pembacaan tanda khususnya program talk show perlu dikembangkan lebih lagi. Hal ini dilakukan mengingat program ini memiliki segmentasi dan paparan tersendiri dalam benak audience, serta banyak meraup perhatian penonton sekaligus pengiklan.

Secara praktis, informasi yang dipaparkan oleh talk show mengangkat tema pribadi, hendaknya disesuaikan karena terpaan terus menerus mengenai keuangan tidak etis untuk disajika dan cenderung berakhir sebagai bualan. Jangan sampai nuansa kapitalis 
yang begitu dominan semakin memperburuk pola pikir dan perilaku masyarakat, sampai akhirnya menganggap utang konsumtif adalah wajar, dan BOLEH dilakukan.

Chandra Dewi memiliki gaya tersendiri dalam menyampaikan ide atau gagasan. Bukan tidak baik atau tidak boleh, tetapi dalam kaitannya dengan bahasa tubuh ataupun kata yang digunakan, hendaknya profesionalitas Chandra Dewi ditingkatkan dan harus lebih mampu menempatkan diri sebagai host yang dilihat dan dinilai oleh masyarakat luas (karena juga tayang di YouTube, bukan hanya televisi saja).

Pengetahuan dan kemampuan menganalisis kiranya perlu untuk menentukan apakah sebenarnya yang diinginkan oleh si media tersebut. Atau mungkin lebih jauh lagi, mungkin hal tersebut hanya disajikan dengan tujuan sebagai sarana pencitraan atas pemilik, pemodal ataupun eksistensi media massa tersebut. Sebagai penikmat atau audience, hendaknya tidak hanya pasrah dalam menerima terpaan yang diberikan oleh televisi. Hendaknya pemirsa menyadari praktik kapitalis dan ekonomi politik media yang ada di media massa, sehingga harus meningkatkan pemikiran kritis terhadap program ataupun tayangan dari media konglomerasi, terlebih dari televisi.

\section{DAFTAR PUSTAKA}

Barthes, R. (2010). Imaji Musik Teks (diterjemahkan oleh Agustinus Hartono). Yogyakarta: Jalasutra.

Berger, P.L dan Luckmann, T. (1990). Tafsir Sosial atas Kenyataan: Risalah tentang Sosiologi Pengetahuan. Terjemahan Hasan Basari Cetakan ke-10. Jakarta: Penerbit LP3ES.

Danesi, M. (2011). Pesan, Tanda dan Makna Buku Teks Dasar Mengenai Semiotika dan Teori Komunikasi. terj. Evi Setyarini dan lusi Lian Piantari. Yogyakarta: Jalasutra.

Danesi, M., \& Admiranto, A. G. (2010). Pengantar memahami semiotika media. Yogyakarta: Jalasutra.

DeVito, J. A. (2012). The interpersonal communication book 13th edition. Pearson.

Martasari, R (2007). Dekonstruksi Host Dalam Talk Show Di Televisi (Analisis Semiotik Talk Show Empat Mata di Trans 7). Diakses dari : http://eprints.umm.ac.id/9258

Piliang, Y.A. (2010). Semiotika dan Hipersemiotika: Gaya, Kode, dan Matinya Makna. Bandung: Penerbit Matahari.

Rusmana, D. (2014). Filsafat Semiotika: Paradigma, Teori, dan Metode Interpretasi Tanda dari Semiotika Struktural Hingga Dekonstruksi Praktis. Bandung: Pustaka Setia.

Selby, K., \& Cowdery, R. (1995). How to study television. Macmillan International Higher Education.

Sihabudin, A. (2011). Komunikasi antarbudaya: suatu perspektif multidimensi. Bumi Aksara. 
Sobur, A. (2009). Analisis Teks Media: Suatu Pengantar untuk Analisis Wacana, Analisis Semiotik, dan Analisis Framing. Bandung: Penerbit PT Remaja Rosda Karya.

Suprapto, T. (2006). Pengantar Teori Komunikasi. Yogyakarta: Media Pressindo.

Wibowo, I. S. (2011). Semiotika Komunikasi: Aplikasi Praktis bagi Penelitian dan Skripsi Komunikasi. Jakarta: Mitra Wacana Media. 